\title{
Effects of Land Crabs on Leaf Litter Distributions and Accumulations in a Mainland Tropical Rain Forest ${ }^{1}$
}

\author{
Peter M. Sherman² \\ School of Natural Resources and Environment, University of Michigan, Ann Arbor, Michigan 48104, U.S.A.
}

\begin{abstract}
The effect of the fossorial land crab Gecarcinus quadratus (Gecarcinidae) on patterns of accumulation and distribution of leaf litter was studied for two years in the coastal primary forests of Costa Rica's Corcovado National Park. Within this mainland forest, $G$. quadratus achieve densities up to $6 \mathrm{crabs} / \mathrm{m}^{2}$ in populations extending along the Park's Pacific coastline and inland for $c a 600 \mathrm{~m}$. Crabs selectively forage for fallen leaf litter and relocate what they collect to burrow chambers that extend from 15 to $150 \mathrm{~cm}$ deep $(N=44)$, averaging $( \pm S E) 48.9 \pm 3.0 \mathrm{~cm}$. Preference trials suggested that leaf choice by crabs may be species-specific. Excavated crab burrows revealed maximum leaf collections of $11.75 \mathrm{~g}$ dry mass2.5 times more leaf litter than collected by square-meter leaf fall traps over several seven-day sampling periods. Additionally, experimental crab exclosures $\left(25 \mathrm{~m}^{2}\right)$ were established using a repeated measures randomized block design to test for changes in leaf litter as a function of reduced crab density. Exclosures accumulated significantly more (5.6 \pm 3.9 times) leaf litter than did control treatments during the wet, but not the dry, seasons over this two-year study. Such extensive litter relocation by land crabs may affect profiles of soil organic carbon, rooting, and seedling distributions.
\end{abstract}

\section{RESUMEN}

Se estudiaron los efectos de los cangrejos terrestres Gecarcinus quadratus (Gecarcinidae) en la acumulación y distribución de hojarasca en el bosque costero primario del Parque Nacional Corcovado, Costa Rica, durante dos años. En este tipo de bosque, $G$. quadratus alcanza densidades de aproximadamente 6 cangrejos $/ \mathrm{m}^{2}$ en poblaciones que se extienden a lo largo de la costa Pacífica, en una franja de aproximadamente $600 \mathrm{~m}$ al interior. Los cangrejos forrajean selectivamente las hojas caídas y las reubican en sus cuevas, que pueden extenderse desde 15 a $150 \mathrm{~cm}$ de profundidad ( $N$ $=44$, media $=48.9 \pm 3.0 \mathrm{~cm}$ ). Mediante experimentos de preferencia se encontró que la selección de hojarasca se restringe a ciertas especies. Se excavaron cuevas de cangrejos y se encontró hasta un máximo de $11.75 \mathrm{~g}$ (peso seco) de hojarasca. Esta cantidad fue 2.5 veces mayor que la cantidad colectada con trampas de hojarasca de un metro cuadrado, durante varios períodos de siete días. Se establecieron cinco clausuras experimentales de $25 \mathrm{~m}^{2}$ en un diseño de bloques al azar de mediciones repetidas para probar cambios en la acumulación de hojarasca en función de la disminución de la densidad de cangrejos. En estas clausuras se acumuló significativamente más (5.6 \pm 3.9 veces) hojarasca que en las clausuras de control en la época lluviosa pero no en la seca, durante los dos años de estudio. Este traslado extensivo de hojarasca que realizan los cangrejos terrestres posiblemente afecta la concentración de carbono orgánico del suelo y la distribución de raíces y plántulas.

Key words: Corcovado National Park; Costa Rica; Gecarcinidae; Gecarcinus quadratus; land crabs; leaf litter distributions; mainland coastal ecosystems; Neotropical rain forest.

The deposition, aCCUMUlation, AND DeCOMPOSITION OF LEAF LITTER represent a major vector for nutrient return to the often nutrient-poor forest soils in both tropical and temperate zones. Therefore, any factors that alter litter accumulation dynamics potentially influence the nutrient cycling process as well. The visually conspicuous influence of land crabs of the family Gecarcinidae has re-

\footnotetext{
${ }^{1}$ Received 27 March 2002; revision accepted 21 March 2003.

${ }^{2}$ Current Address: Arizona International College and the School of Renewable Natural Resources of the University of Arizona, 1609 East Helen Street, Tucson, Arizona 85721, U.S.A.; e-mail: psherman@email.arizona. edu
}

sulted in surprisingly few studies (O'Dowd \& Lake 1989, Kellman \& Delfosse 1993, Sherman 1997, Green et al. 1999). These authors have introduced the importance of terra firme forest-dwelling land crabs on rates of litter removal and decomposition and their potential to alter soil chemistry and rooting distributions (Sherman 1997).

If, however, Gecarcinidae are shown to be responsible for extensive reductions in the litter layer of mainland forests, we may better understand the influence of land crabs on the distributions of nutrients, roots, and seedlings in coastal, pantropical forest ecosystems. To test this, I studied the impact of Gecarcinus quadratus on the distribution of leaf litter, organic carbon, roots, and seedlings in the coastal forest of Costa Rica's Corcovado National 
Park (Sherman 1997). In this paper, I address the following general hypothesis: G. quadratus, living on mainland Costa Rica, manipulate forest leaf litter distributions by selectively relocating a majority of the leaf litter layer from the forest floor into their belowground burrows.

The animal subject and study site.-The land crab Gecarcinus quadratus de Saussure (1853; Gecarcinidae) lives in Neotropical coastal forests and is considered by many to be synonymous with $G_{e-}$ carcinus lateralis (Turkay 1973, Burggren \& McMahon 1988). I conducted this study on the $\mathrm{Pa}-$ cific coast of Costa Rica at the Sirena Biological Station of Costa Rica's Corcovado National Park $\left(8^{\circ} 27^{\prime}-8^{\circ} 30^{\prime} \mathrm{N}, 83^{\circ} 25^{\prime}-83^{\circ} 45^{\prime} \mathrm{W}\right)$. Corcovado N. P. protects 2400 ha of coastal marine habitat and 43,700 ha of wet primary, secondary, and coastal forest extending from sea level to montane forest with mean monthly temperatures ranging between 25 and $26.5^{\circ} \mathrm{C}$ and over $5 \mathrm{~m}$ of rain falling annually (Sirena Station: unpublished field data). A pronounced dry season generally extends from January to April during which $c a 1.0-7.5 \mathrm{~cm}$ of rain falls monthly. Wet season months often exceed 1.0 $\mathrm{m}$ of rain, with the most rain falling from September through November. Gecarcinus quadratus activity, outside the burrow, is highest during the wet season, with peaks from June to August. Gecarcinus quadratus at Sirena Station are nocturnally active (a behavior in marked contrast with all other sites I know of in and out of the park).

Gecarcinus quadratus populate the forested coastline that forms the southern and western extensions of the park (this area termed hereafter the "crab-zone"). The crab-zone at Sirena Station extends inland for $c a 600 \mathrm{~m}$ at which point the soil substrate shifts from sandier coastal soils to clay. This transition zone extends less than $30 \mathrm{~m}$ and crabs clearly associate with the sandier coastal soils. Crab burrow densities range from 0.75 to 6 burrows $/ \mathrm{m}^{2}$, with the highest densities found within $100 \mathrm{~m}$ of the beach. Based upon data from 44 burrow excavations, I assumed 1 crab/burrow (Sherman 1997). Adult crabs dominate the region, ranging from $c a 200$ to $600 \mathrm{~m}$ inland, with burrow densities ranging from 0.75 to $1.7 \mathrm{crabs} / \mathrm{m}^{2}$. I conducted my experiments within this region along the Sirena River trail.

\section{METHODS}

Estimates of anNuAl Leaf LITTER Fall.-To estimate rates of leaf litter fall, I established 23 sam- pling stations along a randomly established, straight line transect from the Sirena Trail through the crab-zone. Stations were established in $5 \mathrm{~m}$ increments along the transect displaced alternately 5 $m$ to the right or left. Each station consisted of a $1 \mathrm{~m}^{2}$ black nylon screening with $1 \mathrm{~mm}^{2}$ mesh suspended $c a 1 \mathrm{~m}$ above the ground by monofilament attached to nearby vegetation. Each trap was at least $10 \mathrm{~m}$ from its nearest neighbor. Litter fall was sampled eight different times. Sampling events ran from seven to ten days and were conducted during July 1994, July 1995 (twice), January 1996, March 1996, and June 1996. Litter was dried and weighed as described below.

To determine leaf litter abundance on the forest floors in and out of the crab-zone, I sampled the two zones in July $1995(N=17$ per region; wet season) and January $1996(N=8$ per region; dry season). I tossed a metal tube of $18 \mathrm{~cm}$ diameter and $20 \mathrm{~cm}$ height $\left(0.025 \mathrm{~m}^{2}\right.$ sampling area) haphazardly onto the forest floor and all litter found within the sampling circle was collected, air-dried, and weighed to the nearest $0.5 \mathrm{~g}$. Comparisons between the two regions were made with an independent samples $t$-test.

Crab exclusion experiment.-Effects of land crab density on leaf litter accumulation were tested using a randomized block design within the crabzone. Five spatially segregated blocks were established, each containing three quadrates $(5 \times 5 \mathrm{~m})$ randomly assigned to one of three treatments (fence-exclosure, fence-control, and open-control). Each block's three quadrates were located on three alternate sides of a hexagon in an attempt to standardize the effects of any quadrate upon any other. Fence-exclosure quadrates were surrounded by a $0.5 \mathrm{~m}$ high wire fence (mesh $2.5 \times 1.25 \mathrm{~cm}$ ). Crabs were live-trapped out of exclosures. Fencecontrol quadrates were surrounded by fencing with holes $(20 \times 20 \mathrm{~cm})$ cut every $60 \mathrm{~cm}$ along the perimeter, permitting crabs movements into and out of quadrates. Open quadrates were also $25 \mathrm{~m}^{2}$ but had no fence and were indistinguishable from open forest.

Within each $25 \mathrm{~m}^{2}$ quadrate, I omitted a 0.5 $\mathrm{m}$ buffer zone around the quadrate perimeter (inside of fence or line boundary) from sampling. From the remaining $16 \mathrm{~m}^{2}$, I randomly selected five plots of $1 \mathrm{~m}^{2}$ for repeated measures analyses of burrow densities and leaf litter samples. From within each $\mathrm{m}^{2}$ plot, litter was sampled from a $0.063(1 / 16 \mathrm{th}) \mathrm{m}^{2}$ subplot without replacement or re-randomization over five sampling periods spaced 
ca 3.0 months apart so that leaf litter collections represented accumulations since the previous collection. A baseline sample was taken one year prior to beginning these repeated measures. All leaf litter collected was air-dried, or oven-dried at $40^{\circ} \mathrm{C}$, and weighed to the nearest $0.5 \mathrm{~g}$ on location. Drying technique did not significantly affect dry weights of samples.

LitTer Removal by Crabs. - To determine if land crabs remove leaves from the forest floor in the crab-zone, I conducted leaf removal experiments during the wet season in July 1994. Thirty-six $A p$ helandra sp. leaves were individually tethered with $2 \mathrm{~m}$ of monofilament. Tethered leaves were placed every $2 \mathrm{~m}$ along a straight-line transect through the crab-zone where the average burrow density was just over $1 / \mathrm{m}^{2}$. The trial was established in the afternoon and information relating to the fates of leaves (as determined by following tethers) was collected 15 hours later the following morning. I also investigated leaf removal rates using marked leaves. One hundred thirty-five leaves of Faramea occidentalis were collected from nearby trees, marked with permanent ink, and set out in groups of three at 45 pin-flag stations. Stations were established $1 \mathrm{~m}$ apart along a random compass direction at 1600 h. Fifteen hours later, remaining leaves were counted and moved leaves were found.

LEAF PREFERENCES. - To determine if crabs exhibited a preference during leaf removal, I provided crabs with four different species of leaves at 75 pin-flag locations. I placed a marked leaf from each of the following four plants: Aphelandra sp. (Acanthaceae), F occidentalis (Rubiaceae), Clusia sp. (vine; Clusiaceae), and Capparis cynophallophora (Capparidaceae). Pin flags were established throughout the crab-zone at least $0.5 \mathrm{~m}$ from the nearest burrow and at least $1 \mathrm{~m}$ from the nearest neighbor flag. Leaves were set out at $1130 \mathrm{~h}$ on 16 July 1994. The following dawn, all remaining leaves were identified and counted. A Pearson's chi-square analysis was used to determine if significant interactions existed between leaf species and presence/absence (crab selection).

RATES OF LITTER RELOCATION BELOW GROUND BY CRABS. - The rates of litter relocation from the soil surface to burrow chambers by individual crabs were estimated by placing known amounts of leaves inside $1 \mathrm{~m}^{2}$ enclosures, each containing one active crab burrow. Trials were conducted in wet and dry seasons. In the first trial (18-25 June 1995), I es- tablished 20 experimental enclosures and 4 control exclosures. I removed all seedlings, propagules, and leaves from the 24 plots prior to the start of each experiment. Into each plot, I placed $25 \mathrm{~g}$ of wet newly fallen green and yellow leaves from dicotyledonous species found within the crab-zone. Leaves chosen included Tocayena pittieri, Foccidentalis, Aphelandra sp., Clusia sp., C. cyanophallophora, Psychotria sp., and Ficus sp. All leaves were washed and towel-dried in the field to remove soil residues that could affect estimates of wet mass. Leaves heavier than $25 \mathrm{~g}$ were cut into pieces and incorporated into the $25 \mathrm{~g}$ input. After seven days, the remaining leaves and leaf parts were collected, washed, cleaned, and weighed to the nearest $0.5 \mathrm{~g}$ wet weight.

The second trial was conducted from $27 \mathrm{De}-$ cember 1996 to 6 January 1997. Twenty-one new enclosures surrounding single crab burrows and three new control plots were established and cleaned of litter and seedlings; crabs were deprived of food for three days. On 30 December, $25 \mathrm{~g}$ of mixed species leaves (see above) were cleaned and placed into each of the 24 plots. Seven days later, leaves were collected, air-dried, and weighed to the nearest $0.5 \mathrm{~g}$.

Statistical analyses.-Crab exclusion experiment: I estimated the effects of treatment, block, and time on leaf litter accumulation as a function of crab access using a repeated measures two-way ANOVA within a randomized block design. Treatment (fence-exclosure, open-control, and fencecontrol) and spatially segregated blocks $(N=5)$ were the two between-subjects factors, and time was the within-subjects repeated measure using $c a$ 3-month increments (July and October 1995; January, March, and July 1996). Although exclosure and fence-control baseline litter weights were significantly greater than the open-control treatment, I did not use baseline as a covariate because litter sampling was done without replacement such that after each sampling period, all plots were reset to zero. In response to a long-standing and unresolved debate among the authors of statistics texts regarding the analysis of experiments involving blocking factors that are neither, strictly speaking, random nor fixed effects, I followed the advice of Newman et al. (1997) and conducted two analyses. For a discussion of their relative merits and uses as appropriate to this design, see Sherman (2002). As the results from the two analyses were similar, I present only those from model 2 . Alpha was set to 0.05 and two-tailed probabilities were used for all 
analyses. All expressions of variation are standard errors of the estimate.

\section{RESULTS}

TEMPoral and spatial ESTIMATES OF litTter fall and ACCUMULATION. - The fall and accumulation of leaf litter varied seasonally and spatially at Corcovado National Park. The standing stock of leaf litter on the forest floors of the crab-zone was greater than in the crabless-zone for both the wet and dry seasons $(T=3.1, \mathrm{df}=14, P=0.006$ and $T=4.4$, df $=7, P=0.003$, respectively). The average leaf litter collection from litter traps suspended in the crab-zone was $0.6 \pm 0.1 \mathrm{~g}$ dry leaf litter $/ \mathrm{m}^{2} / \mathrm{d}(N$ $=7$ sampling periods). Significantly lower leaf weight, however, was collected during the wet season than the dry season $(0.5 \pm 0.03$ vs. $0.9 \pm 0.07$ $\mathrm{g}$ dry weight $/ \mathrm{m}^{2}$; Mann-Whitney $U=12, P=$ 0.04).

LEAF LITTER ACCUMULATION IN THE RANDOMIZED BLOCK EXPERIMENT.- Average baseline leaf litter dry mass was $9.2 \pm 1.4 \mathrm{~g} / 0.063 \mathrm{~m}^{2}$ found for all quadrates ( $N=15$ quadrates; 75 plots) or $c a 150 \mathrm{~g}$ dry $\mathrm{wt} / \mathrm{m}^{2}$. Baseline leaf litter accumulation was similar between exclosures and fence-control quadrates at $12.1 \pm 1.9$ and $10.6 \pm 1.6 \mathrm{~g}$, respectively, but these values were more than double the values for open quadrates of $5.2 \pm 0.7 \mathrm{~g}(F=7.5, \mathrm{df}=2$, $P=0.001)$. Variation in baseline leaf litter accumulation was also found between quadrates, which ranged from $0.6 \pm 0.4 \mathrm{~g}$ dry weight $/ 0.063 \mathrm{~m}^{2}$ to $19.4 \pm 5.7 \mathrm{~g}(N=5$ for each value), but analyzed together were not statistically significant $(F=3.1$, $\mathrm{df}=4,8 ; P=0.08$ ).

Over the next two years, the experimental exclusion of crabs resulted in a significant, although inconsistent, increase in litter standing stock rela- tive to both controls (Table 1). The average leaf litter weights for each of the three treatments calculated over all sampling periods (excluding baseline) revealed that exclosures contained nearly double the leaf litter $(11.2 \pm 2.3 \mathrm{~g}$ dry litter/0.063 $\left.\mathrm{m}^{2}\right)$ compared to open $(4.6 \pm 1.6 \mathrm{~g})$ and fencecontrol $(5.9 \pm 2.3 \mathrm{~g})$ treatments. The patterns, and absolute amounts, of litter accumulation, however, varied significantly between seasons, with greater standing stocks of litter accumulating during the dry season samples (Fig. 1). Repeated measures ANOVA (models 1 and 2) indicated a significant effect of treatment (exclosures), block (spatial heterogeneity), and time (seasonality) on litter accumulations.

In October 1995, exclosure quadrates contained more leaf litter than the average of both control treatments (Fig. 1). Beginning in January and continuing through March 1996, the litter accumulations in the exclosures increased 122 percent over October values while accumulation in the control treatments increased an average of 165 percent, revealing both the increased leaf fall and decreased crab activity associated with the regional dry season. The January pattern of litter accumulation also revealed a spatial heterogeneity not found in either October or March. With the returning rains in April, leaf fall diminished, crab activity resumed, and litter accumulations in all three treatments decreased. While control quadrates returned to low October values, exclosures remained 39 percent above October's sample, resulting in a visually apparent treatment effect by July 1996. Spatial heterogeneity in litter accumulations, however, was apparent among the blocks.

LEAF LITTER REMOVAL AND SPECIES PREFERENCES.Tethered and marked leaves placed out overnight were taken selectively to their burrows by crabs.

TABLE 1. Results from crab exclusion experiment documenting effects of land crabs on changing accumulations of leaf litter. Repeated measures ANOVA uses a fixed treatment factor (exclosure, open-control, and fence-control) and a random blocking factor over two years of sampling. Whether spatially separated blocks can be assumed to be arbitrarily defined or to be part of a larger population of blocks is debatable. Therefore, two models of ANOVA were conducted (Newman et al. 1997). As both models revealed similar results, only model 2 is presented.

\begin{tabular}{llrrrrr}
\hline MODEL II ANOVA & \multicolumn{1}{c}{ Source } & SS & df & MS & $F$ & $P$ \\
\hline Between-Subjects: & Treatment & 597 & 2 & 298 & 14.7 & $\ll 0.01$ \\
& Block & 348 & 4 & 87 & 4.3 & $<0.01$ \\
& Time & 1152 & 4 & 288 & 14.2 & $\ll 0.01$ \\
& Time*Treatment & 146 & 8 & 18 & 0.9 & NS \\
& Time*Block & 248 & 16 & 15 & 0.8 & NS \\
Within-Subjects: & Time*Treatment*Block & 650 & 32 & 20 & & \\
\hline
\end{tabular}




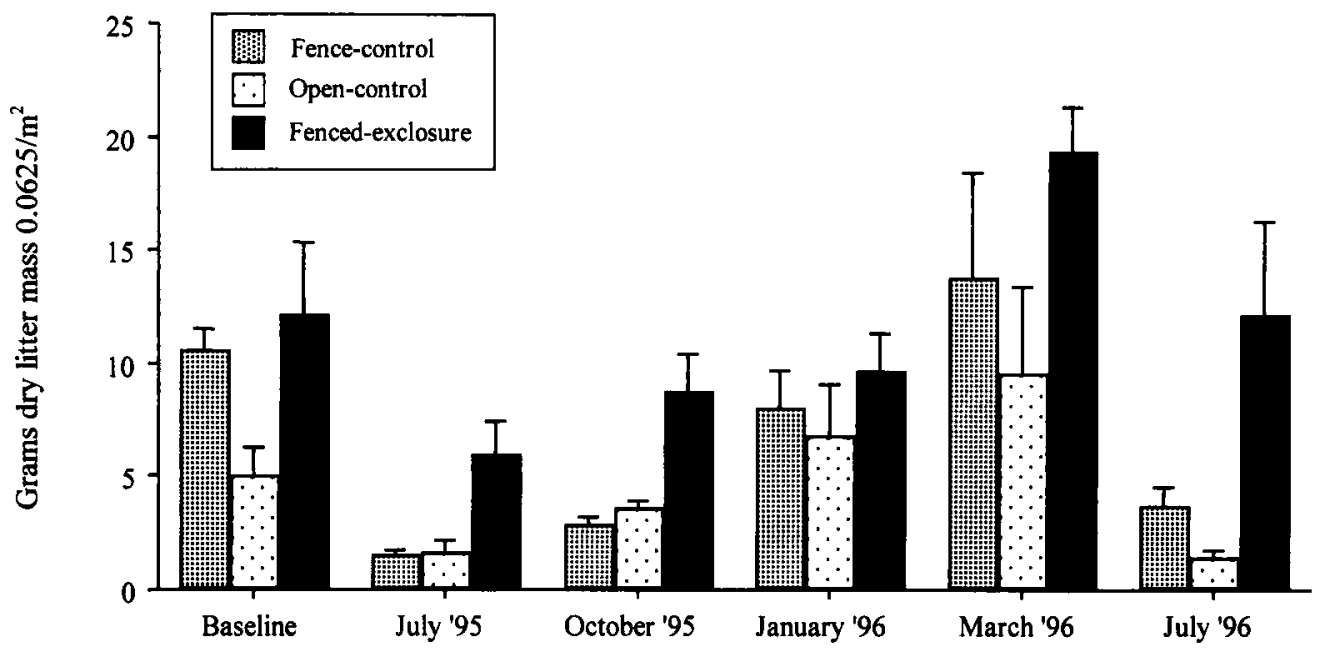

Dry Season $=$ Crab Inactivity

FIGURE 1. Average ( \pm SE) leaf litter ( $\mathrm{g}$ dry mass $0.0625 \mathrm{~m}^{-2}$ ) accumulation since previous sampling period as a function of experimental treatment and time. Baseline samples represent preexperimental standing stock. Each datespecific sample value represents 25 litter collections taken from five plots from each of five quadrates comprising a single treatment. Statistically significant treatment effects occurred only for wet season samples.

Fifteen hours after placing 36 green leaves of $A p$ helandra sp. into the crab-zone, 61 percent of the 36 tethered leaves were found in crab burrows; 25 percent of the leaves and tethers were missing altogether; 8 percent of the leaves were gone and only their snipped tethers were found; and 6 percent of the leaves were found dragged to the exterior of burrow entrances. In a second set of leaf relocation trials with marked leaves of $F$ occidentalis, 96 percent of the leaves (129/135) had been removed from the area (defined as not being within $5 \mathrm{~m}$ of a given station) after 17 hours. A majority of these marked leaves were found over the next several days within burrow entrances, presumably as crabs cleaned out litter debris from their homes.

Gecarcinus quadratus demonstrated strong species preferences among four different species of leaves tested. Twenty-four hours after setting out one leaf of each of four dicotyledonous species around 75 pin-flag stations, 37.3 percent of the leaves had been moved to burrows. Three of the four species (Faramea, Aphelandra, and Clusia) were removed from pin-flag stations at roughly similar rates $(45.7 \pm 2.7 \%)$ while only 12 percent of $C$. cynophallophora leaves was removed $\left(\chi^{2}=\right.$ $38.1, \mathrm{df}=9, P<<0.001)$. These data suggest that $G$. quadratus forage selectively for fallen leaves but may have broad diets.
Rates of litTer relocation below ground.Crabs kept individually in enclosures for one week removed an average of $39.1 \pm 5.3$ percent (or 9.8 $\pm 1.4 \mathrm{~g}$ ) of the $25 \mathrm{~g}$ wet leaf litter mass provided. These wet weight data convert to $3.1 \pm 0.9 \mathrm{~g}$ of $8 \mathrm{~g}$ dry litter removed per week during the wet season trials. A dry season trial, run in January 1996 during unseasonably heavy rains (higher crab activity rates), gave a slightly higher estimate of belowground leaf relocation. From 21 caged enclosures, into each of which $25 \mathrm{~g}$ wet leaf litter was placed, crabs removed an average of $54.2 \pm 5.2$ percent of the litter during the seven-day trial, or $4.2 \pm 0.4 \mathrm{~g}$ dry leaf $/ \mathrm{m}^{2} / \mathrm{wk}$.

LEAF LITTER CONTENTS OF BURROW CHAMBERS. - Of 44 burrows excavated over the two-year study, 1 was unoccupied and all others contained a single crab. Average burrow depth was $48.9 \pm 3.0 \mathrm{~cm}(N=$ 44) and average burrow length was $74.6 \pm 5.4 \mathrm{~cm}$ $(N=37)$. Sixteen of these burrows were excavated in such a way that chambers were sampled for leaves. An average of $3.9 \pm 1.1 \mathrm{~g}$ dry litter was found in 15 of them $(\min =0.25 \mathrm{~g}, \max =11.75 \mathrm{~g}$ dry $)$.

\section{DISCUSSION}

Patterns of leaflessness in the crab-zone: DeSCRIPTIVE AND EXPERIMENTAL ASSESSMENTS.-During 
the wet season in Corcovado National Park, when dense populations of the land crab G. quadratus experience their highest rates of activity, leaf litter fails to accumulate over extensive areas of this flat, coastal forest floor. These nearly leafless regions are exclusive to the crab-zone that extends along the peninsula's coastline and inland for up to $600 \mathrm{~m}$ and starkly contrast with the remainder of the interior forest that expands for tens of thousands of hectares where a conspicuous, thick layer of leaf litter accumulates year-round. Localized exceptions in this larger pattern exist within the crab-zone, however, where pockets of accumulating leaf litter form under certain trees during the wet season. Pockets of accumulation probably reflect variations in both leaf abscission phenologies (Proctor 1984, Scott et al. 1992, Stocker et al. 1995) and leaf preferences by crabs, as demonstrated here and elsewhere (Kellman \& Delfosse 1993, Micheli 1993b, Kwok \& Lee 1995).

Additionally, during the dry season, which generally extends from 2.5 to 4 months, a thin but ubiquitous layer of intact leaves often accumulates in the crab-zone. This repeated pattern likely reflects the seasonally higher leaf fall rates that are common to many tropical forests and the relative and temporary inactivity of the crabs. To the eye, this accumulation represents a conspicuous increase from wet season conditions, but the leaves are dry and do not amount to much more than a thin layer of litter. With neither requisite time nor humidity to fully decompose, a substantial humus layer cannot develop where the crabs live. Yet, less than 50 $m$ further inland, where crabs do not live (crablesszone), litter accumulates and humus forms yearround. The artificially designed "crabless" zones of the exclusion experiment also reached their highest litter accumulations during the dry season. And yet the peaks of litter accumulation from within the two control treatments revealed a co-influence of both litter fall and crab inactivity (Fig. 1). During this period when crabs were inactive, litter could accumulate throughout the crab-zone and treatment effects on litter accumulation became insignificant. After the rains returned and the crabs resumed activity, the effects of the exclosure treatment reemerged, with exclosures collecting twice to three times the amount of litter as control quadrates. Variation in litter accumulation among the five exclosures, however, likely reflected the natural variation in leaf fall phenologies of the trees immediately above the quadrates.

The seasonal accumulation throughout the crab-zone may be meaningful to the young plants of the area. It is certainly plausible that this thin leaf layer may provide a higher and more constant moisture microclimate for seeds that are subjected to the intense sun that penetrates through the relatively thin dry season canopy. Coupled with low crab activities during these months, seedlings growing from larger seeds may rely upon this temporal window of opportunity to grow beyond the preferred size range of foraging $G$. quadratus, which have been shown to selectively devastate local populations of seedlings (Sherman 1997, 2002).

ASSESSING RATES OF LITTER REMOVAL BY LAND CRABS.-Leaf tethering, performed here and elsewhere, has demonstrated that land and mangrove crabs relocate fallen leaves to their burrows (Robertson 1986, Robertson \& Daniel 1989, Emmerson \& McGwynne 1992). Others have shown that crab leaf choice is selective (Giddins et al. 1986, Camilleri 1989, O’Dowd \& Lake 1989, Emmerson \& McGwynne 1992, Micheli 1993b) and that such selectivity may result in variable growth and reproductive rates for the crabs (Micheli 1993a). In two trials in which I placed marked or tethered leaves onto the forest floor in the crab-zone, crabs removed a majority of leaves presented in one night.

Of the three currently published studies that have estimated rates of leaf litter removal by species of the family Gecarcinidae, a preliminary pattern emerges: land crabs acting upon insular island forest systems (O'Dowd \& Lake 1989, Green et al. 1999) may have stronger effects than those crabs acting in more diverse forest regions of the mainland tropics (Kellman \& Delfosse 1993). Several variables, beyond the island/mainland comparison, confound our ability to confidently draw a conclusion from these two study systems. For example, different methods were used to estimate litter removal rates in the three studies and different species of crabs were studied living in different hemispheres. Crab densities, however, were similarly high in both sites and comparable to those of Corcovado.

O'Dowd and Lake (1989), using a paired sample trap design that provided or prevented crab access to leaves, estimated that from 30 to 50 percent of leaf litter is relocated from the forest floor to burrow chambers by crabs. Studying the same population of crabs, Green et al. (1999) refined the previous estimates describing removal rates from 39 (by sampling inside and outside exclosures) to 87 percent (by monitoring disappearance rates of marked leaves). Additional burrow excavations re- 
vealed that 14 of 22 burrows had litter that lined the chambers (Green et al. 1999). I similarly found that 15 of 16 inhabited burrows contained $3.9 \pm$ $1.1 \mathrm{~g}$ dry leaf litter.

Kellman and Delfosse (1993) used five $1 \mathrm{~m}^{2}$ crab exclosures paired with open plots (replicated in two sites) to estimate litter removal rates. They sampled over two-week intervals during four months of the wet season and concluded that land crabs manipulated 11 percent of the available litter, a percentage value considerably lower than estimates from O'Dowd and Lake (1989) and Corcovado. They did find, however, that leaf litter accumulation nearly doubled in exclosures relative to open plots during the dry season when decomposition rates were reduced. These findings suggest that the mainland Mexican system is less strongly affected by land crabs than the Corcovado system described herein. In contrast to Kellman and Delfosse (1993), I found that the wet season promoted the greatest differences between litter accumulations of exclosures and controls-presumably because crabs were active-and that during the dry season, when crabs were inactive and more leaves fell, treatment differences became temporarily insignificant. In this way, my finding is markedly dissimilar and may relate to differences in tree communities (differences in phenology and leaf nutrition), climate, soil structures, decomposition rates, and crab activity patterns.

Kellman and Delfosse (1993), however, discovered that crabs effectively increased the rate and intensity of litter removal in Veracruz such that open plots were described as bare sand, whereas exclosures supported a constant litter layer that permitted the formation of humus. These findings qualitatively corroborate my own observations of rapid, non-crab related, leaf litter decomposition on the sandy soils during the wet season. Nevertheless, as in Veracruz, my exclosures were capable of accumulating a deep litter layer that after two years allowed humus formation and infiltration of fine roots and fungal hyphae, which were conditions I never observed in the open or fence-control treatment quadrates, or in the natural crab-zone forest. This relatively subtle finding can have a major impact on soil microsite conditions, soil microbial and invertebrate communities, and on organisms (e.g., plants) that rely upon a more biologically active soil substrate.

Much work exists from mangrove systems and the reports seem to consistently implicate mangrove crabs as a major factor in litter removal. Although I will not attempt to review that literature here, a few examples demonstrate the general pattern. Robertson (1986) estimated leaf litter removal rates by sesarmid crabs in an Australian mangrove system by tethering leaves and comparing these values to leaf fall rates. He estimated that from 22 to 42 percent of the daily influx of leaf litter was removed by crabs; these values converted to an annual relocation rate of 28 percent of the litter. Robertson and Daniel (1989) reported annual leaf litter removal rates, as determined by a paired litter trap design (with and without crab access), from three different mangrove forests. Their results demonstrated that leaf litter removal rates differ between systems ranging from 24.4 percent in Avicennia marina forests to 60 percent in Bruguiera exaristata and 92 percent in Ceriops tagal forests. These authors have suggested that these widely varying litter removal rates relate largely to different foraging behaviors among the members of crab communities that inhabit the three mangrove forests (see also McIvor \& Smith [1995] for more variable findings).

Additionally, Robertson and Daniel (1989) measured rates of microbial turnover of litter and concluded that crabs processed leaf litter 75 times faster than did the microbial community alone. Robertson and Daniel (1989) remarked that only one other paper, prior to their own, investigated comparable questions. Leh and Sasekumar (1985) estimated that two sesarmid crabs in Malaysia could remove up to 30 percent of the annual leaf litter accumulation from their habitats. Since then, Emmerson and McGwynne (1992) have used a laboratory-based mathematical approach to determine the effects of sesarmid crabs on mangrove litter removal. They used laboratory feeding trials in which consumption rates were determined per crab per day and then incorporated leaf fall data, crab density, and biomass to conclude that crabs removed 44 percent of the annual leaf fall.

These and a few other published studies (Camilleri 1989; Lee 1989, 1997; Hill \& O'Keeffe 1992; Micheli 1993b; Twilley et al. 1997; Dahdouh-Guebas et al. 1999; to the best of my knowledge, a comprehensive listing of the English-language literature), serve to build a strong case for crabs (of several families) as agents of litter removal and nutrient manipulation. My design to estimate the average rate of leaf litter removal per crab over one week differed from these previous efforts. By enclosing crabs with known amounts of leaf litter, I was able to factor out several potentially confounding variables. My design, for example, either controlled or took into account other macrofaunal 
and microfaunal leaf damage, short-term non-crab decomposition, and dirt and moisture accumulation. A major weakness in my effort was the brief duration of the trials and the additional need to further replicate the trials throughout the seasons. Nevertheless, the pattern is clear: crabs of both mangrove and terra firme forested systems selectively altered rates of leaf litter accumulation and decomposition.

Two additional considerations about crab biology and forest ecology may improve our understanding of crab-litter dynamics. The crabs do not consume the entire leaf, and sloppy eating habits may reduce particulate size of the organic matter on the soil surface (Camilleri 1992) and in the burrow chambers (Micheli 1993b). Smaller particulate organic matter can be more rapidly colonized by microfauna and microorganisms than can larger particles (Hanlon 1982). Additionally, nutrientrich crab excrement accumulates in and around burrow entrances and chambers (Kellman \& Delfosse 1993, Lee 1997, Sherman 1997). Therefore, although litter may be brought down and consumed in burrows to a depth of $1 \mathrm{~m}$, fecal placement may ultimately override the effects of litter relocation on nutrient distributions and the community members that exploit them.

ARE LAND CRABS THE EARTHWORMS OR TERMITES OF THE COASTAL NEOTROPICS?-Anderson and Swift (1983) have asserted that macro- and mesofaunal foraging behavior patterns represent the major mechanism by which intact litter disappears from the tropical forest floor. In temperate systems, earthworms play an important role in litter decomposition through the relocation of leaf litter deeper into the soil profile (Hendrix 1996). Tropical forests, however, are thought to support a lower earthworm biomass, and a common perception is that no known families of tropical earthworm relocate leaf litter below ground (Anderson \& Swift 1983). A more recent review has suggested, however, that anecic species of earthworm (those that relocate decomposing litter into their burrows) actually dominate the soil macrofauna (termites, ants, and such) of some tropical forests (Fragoso \& Lavelle 1992). Nevertheless, Corcovado's crab-zone does not appear to represent one of these forests, and soildwelling earthworms are quite uncommon in the crab-zone, possibly due to the sandy soils. Termites represent important litter decomposers for many Old World tropical systems (Holt 1987), but those species that feed on intact litter are also largely absent from the Neotropics (Anderson \& Swift 1983; cf. Martius 1994). Leaf cutter ants represent a third and conspicuous vector of litter relocation from above to below ground. Leaf cutters, however, generally relocate live leaf material from the forest canopies to central, localized nest chambers decp below ground. In contrast, land crabs individually transport previously fallen leaf litter from the forest floor to their burrows, which are essentially uniformly distributed across the forest floor and descend down to less than $1 \mathrm{~m}$; the dynamics are quite different. With coastal and mangrove rain forests often supporting a relatively uniform distribution of crab densities of over $10,000 /$ ha, crabs may serve a similar role to the earthworms of the temperate zone or the termites of the Old World tropics, but on even a more intensive scale.

LEAF LITTER MANIPULATION AND ITS EFFECTS ON PLANT COMMUNITY COMPOSITION.-Land crabs manipulate the leaf litter layer, and in so doing, may alter soil microsite conditions, patterns of seedling emergence and development, and litter faunal communities (Sherman 1997, Green et al. 1999). The importance of litter in forest ecology has been well studied (see reviews in Howe \& Smallwood 1982, Facelli \& Pickett 1991a). Leaf litter can affect plant propagation in many ways. For example, leaf litter influences soil micronutrients and their cycling (McClaugherty et al. 1985); leaches phytotoxins and modifies allelopathic interactions (see review in Rice 1984); acts as a physical barrier to growth (Peterson \& Facelli 1992, Reader 1993); blocks light thereby changing soil moisture and temperature regimes (Molofsky \& Augspurger 1992); protects propagules from predation (Reader $\&$ Beisner 1991); provides habitat for invertebrates that may be herbivorous or predatory (Reader 1991); and influences the competitive outcomes between seedlings (Facelli \& Pickett 1991b). Through their relocation of leaf litter from the soil surface to belowground burrows, individual land crabs may influence soil microsite conditions; however, in forest regions such as Corcovado where crab densities commonly range from 10,000 to $60,000 \mathrm{crabs} / \mathrm{ha}$, land crab manipulation of leaf litter can reach ecosystem-level importance. As expansive regions of rain forest can be seasonally cleared of surface leaf litter, land crabs may act as important modifiers of both floristic and faunal communities and the abiotic foundation upon which they rely. Ultimately, land crabs (as well the mangrove families Sesarmidae and Grapsidae) may be shown to exemplify a dominant taxon in the control and maintenance of biodiverse forest systems in the coastal tropics. 


\section{ACKNOWLEDGMENTS}

I thank David Allan, Gary Fowler, Barb Smuts, Earl Werner, and Donald Zak for improving the original dissertation and two essential reviewers of this manuscript: Erika Deinert and Greg Gilbert. The work would have been impossible without the following field assistants: Ted Lee, Mark George, Dario Primo, Ben Gillette, David Walther, Leslie Patton, Andy Stubblefield, Adam Ringia, Michael Ebinger, Patryce Avsharian, and Bret Freeman. I especially thank Larry Gilbert and Paulino Valverde. This effort was funded by the National Science Foundation Dissertation Improvement Grant no. 033703, the Charles A. and Anne M. Lindbergh Foundation-Harry Frank Guggenheim Fellowship, Hewlett Foundation, Organization for Tropical Studies, University of Michigan's Rackham PreDoctoral Fellowship, Rackham Dissertation and Discretionary Grants, School of Natural Resources and Environment, and the Latin American and Caribbean Studies Program.

\section{LITERATURE CITED}

Anderson, J. M., and M. J. Swift. 1983. Decomposition in tropical forests. In S. L. Sutton, T. C. Whitmore, and A. C. Chadwick (Eds.). Tropical rain forest: Ecology and management, pp. 287-310. Special publication series no. 2 of the British Ecological Society. Blackwell Scientific, Oxford, England.

Burgcren, W., and R. McMahon. 1988. Biology of the land crabs. Cambridge University Press, Cambridge, England. Camillerı, J. C. 1989. Leaf choice by crustaceans in a mangrove forest in Queensland. Marine Biol. 102: $453-459$. . 1992. Leaf-litter processing by invertebrates in a mangrove forest in Queensland. Marine Biol. 114: 139 145.

Dahdouh-Guebas, F., M. Giuggioli, A. Oluoch, M. Vannini, and S. Cannicci. 1999. Feeding habits of nonocypodid crabs from two mangrove forests in Kenya. Bull. Marine Sci. 64: 291-297.

Emmerson, W. D., and L. E. MCGwrnne. 1992. Feeding and assimilation of mangrove leaves by the crab Sesarma meinerti in relation to leaf-litter production in Mgazana, a warm-temperate southern African mangrove swamp. J. Exp. Marine Biol. Ecol. 157: 41-53.

Facelli, J. M., And S. T. A. PicketT. 1991a. Plant litter: Its dynamics and effects on plant community structure. Bot. Rev. 57: 2-32.

—, AND - 1991b. Indirect effects of litter on woody seedlings subject to herb competition. Oikos 62: $129-138$.

Fragoso, C., and P. Lavei.le. 1992. Earthworm communities of tropical rain forests. Soil Biol. Biochem. 24: 13971408.

Giddins, R. L., J. S. Lucas, M. J. Neilson, and G. N. Richards. 1986. Feeding ecology of the mangrove crab Neosarmatium smithi (Crustacea: Decapoda: Sesarmidae). Marine Ecol. Prog. Ser. 33: 147-155.

Green, P. T., D. O'Dowd, and S. LAKE. 1999. Monopolization of litter processing by a dominant land crab on a tropical oceanic island. Oecologia 119: 435-444.

HanLON, A. 1982. The breakdown and decomposition of alochthonous and autochthonous plant litter in an oligotrophic lake. Hydrobiologia 88: 281-288.

HENDRIX, P. F. 1996. Nearctic earthworm fauna in the southern USA: Biodiversity and effects on ecosystem processes. Biodiv. Conserv. 5: 223-234.

HiLl, M. P., AND J. H. O'KEEFFE. 1992. Some aspects of the ecology of the freshwater crab (Potamonautes perlatus Milne Edwards) in the upper reaches of the Buffalo River, Easter Cape Province, South Africa. S. Afr. J. Aquat. Sci. 18: $42-50$.

Holt, J. A. 1987. Carbon mineralization in semi-arid northeastern Australia: The role of termites. J. Trop. Ecol. 3: 255-263.

Howe, H. F., and J. Smallwood. 1982. Ecology of seed dispersal. Annu. Rev. Ecol. Syst. 13: 201-228.

Kel.lman, M., and B. Delfosse. 1993. Effect of the red land crab (Gecarcinus lateralis) on the leaf-litter in a tropical dry forest in Veracruz, Mexico. J. Trop. Ecol. 9: 55-65.

Kwok, P. W., AND S. Y L.EE. 1995. The growth performances of two mangrove crabs, Chiromanthes bidens and Parasesarma plicata under different leaf-litter diets. Hydrobiologia. 295: 141-148.

LEE, S. Y. 1989. The importance of sesarminae crabs Chiromanthes spp. and inundation frequency on mangrove Kandelia candel L. Druce leaf litter turnover in a Hong Kong tidal shrimp pond. J. Exp. Marine Biol. Ecol. 131: $23-44$.

1997. Potential trophic importance of the faecal material of the mangrove sesarmine crab Sesarma messa. Marine Ecol. Prog. Ser. 159: 275-284.

Leh, C. M. U., and A. Sasekumar. 1985. The food of sesarmid crabs in Malaysian mangrove forests. Malay. Nat. J. 39: 135-145.

Martius, C. 1994. Diversity and ecology of termites in Amazonian forests. Pedobiologia 38: 407-428.

McClaugherty, C. A., J. Pastor, J. D. Aber, and J. M. Melillo. 1985. Forest litter decomposition in relation to soil nitrogen dynamics and litter quality. Ecology 66: 266-275.

McIvor, C. C., AND T. J. SmITH III. 1995. Differences in the crab fauna of mangrove areas at a southwest Florida and a northeast Australian location: Implications for leaf-litter processing. Estuaries 18: 591-597.

Micheli, F. 1993a. Effect of mangrove litter species and availability on survival, moulting, and reproduction of the mangrove crab Sesarma messa. J. Exp. Marine Biol. Ecol. 171: 149-163. 
1993b. Feeding ecology of mangrove crabs in north eastern Australia: mangrove litter consumption by Sesarma messa and Sesarma smithii. J. Exp. Marine Biol. Ecol. 171: 165-186.

Molofsky, J., and C. K. Augspurger. 1992. The effect of leaf-litter on early seedling establishment in a tropical forest. Ecology 73: 68-77.

Newman, J. A., J. Bergelson, and A. Grafen. 1997. Blocking factors and hypothesis tests in ecology: Is your statistics text wrong? Ecology 78: 1312-1320.

O'DOWD, D. J., AND P. S. LAKE. 1989. Red crabs in rain forest, Christmas Island: removal and relocation of leaf fall. J. Trop. Ecol. 5: 337-348.

Peterson, C. J., and J. M. Facelli. 1992. Contrasting germination and seedling growth of Betula alleghaniensis and Rhus typhina subjected to various amounts and types of plant litter. Am. J. Bot. 79: 1209-1216.

Proctor, J. 1984. Tropical forest litterfall II. The data set. In A. C. Chadwick and S. L. Sutton (Eds.). Tropical rain forest: Ecology and management, pp. 267-273. Supplementary volume. Proceedings of the Leeds Philosophical and Literary Society. Oxford University Press, Boston, Massachusetts.

READER, R. J. 1991. Control of seedling emergence by ground cover: A potential mechanism involving seed predation. Can. J. Bot. 69: 2084-2087.

1993. Control of seedling emergence by ground cover and seed predation in relation to seed size for some old-field species. J. Ecol. 81: 169-175.

- AND B. E. Beisner. 1991. Species-dependent effects of seed predation and ground cover on seedling emergence of old-field forbs. Am. Midl. Nat. 126: 279-286.

RuCE, E. L. 1984. Allelopathy. Academic Press, London, England.

Robertson, A. I. 1986. Leaf-burying crabs: their influence on energy flow and export from mixed mangrove forests (Rhizophora spp.) in northeastern Australia. J. Exp. Marine Biol. Ecol. 102: 237-248.

, AND P. A. DANIEL. 1989. The influence of crabs on litter processing in high intertidal mangrove forests in tropical Australia. Oecologia 78: 191-198.

SCott, D. A., J. Proctor, AND J. Thompson. 1992. Ecological studies on a lowland evergreen rain forest on Maracá Island, Roraima, Brazil. II. Litter and nutrient cycling. J. Ecol. 80: 705-717.

Sherman, P. M. 1997. Direct and indirect effects of the land crab Gecarcinus quadratus (Gecarcinidae) on seedling density, organic carbon distributions and rooting profiles in Corcovado National Park, Costa Rica. Ph.D. dissertation. University of Michigan, Ann Arbor, Michigan.

2002. Effects of land crabs on seedling densities and distributions in a mainland Neotropical rain forest. J. Trop. Ecol. 18: 67-89.

Stocker, G. C., W. A. Thompson, A. K. Irvine, J. D. Fitzimon, and P. R. Thomas. 1995. Annual patterns of litterfall in a lowland and tableland rainforest in tropical Australia. Biotropica 27: 412-420.

TurkaY, M. 1973. Bermerkungen zu elnigen Landkrabben (Crustacea, Decapoda). Bull. Mus. Nat. Hist. (Paris) 142: 969-980.

Twilley, R. R., M. Pozo, V. H. Garcia, V. H. Ruvera-Monroy, R. Zambrano, and A. Bodero. 1997. Litter dynamics in riverine mangrove forests in the Guayas River estuary, Equador. Oecologia 111: 109-112. 